\title{
Pengembangan Media Pembelajaran Animasi Powtoon pada Mata Pelajaran Matematika di Kelas IV SD
}

\section{Izomi Awalia', Aan S. Pamungkas², dan Trian P. Alamsyah ${ }^{3}$}

\author{
1,2,3 Jurusan Pendidikan Guru Sekolah Dasar, Universitas Sultan Ageng Tirtayasa Banten
}

Corresponding Author: awaliaizomi@gmail.com

DOI: http://dx.doi.org/10.15294/kreano.v10i1.18534

Received : March 2019; Accepted: April 2019; Published: June 2019

\begin{abstract}
Abstrak
Penelitian ini bertujuan untuk mengembangkan media pembelajaran animasi PowToon pada mata pelajaran matematika di kelas IV, khususnya materi keliling dan luas bangun datar. Penelitian ini merupakan jenis penelitian dan pengembangan atau Research and Development (R\&D) dengan menggunakan model 4-D (define, design, development, and disseminate). Subjek penelitian ini adalah siswa kelas IV SDN Karangtumaritis yang berjumlah 22 siswa. Data dikumpulkan dengan tes, observasi, angket, dan dokumentasi. Analisis data dilakukan dengan analisis deskriptif. Hasil penelitian didapatkan, 1) skor rata-rata dari validasi ahli dengan persentase sebesar $88 \%$ yang termasuk dalam kategori "sangat layak"; 2) skor rata-rata kepraktisan dengan persentase sebesar 93,33\% yang termasuk dalam kategori "sangat praktis"; 3) skor rata-rata dari respon siswa dengan persentase sebesar 94,73\% yang termasuk dalam kategori "sangat baik"; 4) skor rata-rata dari post test sebesar 76,14 yang termasuk dalam kategori baik sehingga dapat disimpulkan bahwa media pembelajaran animasi PowToon dapat memberikan pemahaman kepada siswa kelas IV mengenai mata pelajaran matematika pada materi keliling dan luas bangun datar.
\end{abstract}

\begin{abstract}
This research aims to develop PowToon animation learning media on mathematical subjects in grade IV, especially on the material circumference and area of plane. This research was the kind of Research and Development (R\&D) using the 4-D model (define, design, development, and disseminate). The subject of this research was the grade IV SDN Karangtumaritis with totalling 22 students. Data collected with the tests, observation, question form, and documentation. Data analysis was done with a descriptive analysis. The research results obtained, 1) the average score of validation experts with percentage of $88 \%$ that are included in the category of "highly feasible"; 2) the average score of practicality with a percentage of $93,33 \%$ is included in the category of "very practical"; 3) score the average of the percentage of students with response $94,73 \%$ are included in the categories "excellent"; 4) the average score of the post test of 76,14 are included in the categories "good" so it can be concluded that the PowToon animation learning media can give insight to grade IV on subjects of mathematics on the material circumference and area of plane.
\end{abstract}

Keywords: learning media; powtoon animation; mathematics

\section{PENDAHULUAN}

Perkembangan teknologi mengubah tugas guru dari pengajar yang bertugas menyampaikan materi pelajaran menjadi fasilitator yang memberikan kemudahan dalam belajar. Perkembangan teknologi yang semakin ce- pat memunculkan pertanyaan terhadap tugas guru sebagai pengajar, masihkah guru diperlukan mengajar di depan kelas seorang diri, menuliskan materi di papan tulis kemudian menugaskan siswa untuk menyalinnya, dan sebagainya. Untuk itu, guru harus senantiasa 
mengembangkan potensinya secara professional sesuai dengan perkembangan teknologi saat ini sehingga tugas guru sebagai pengajar masih tetap diperlukan.

Menurut Barnawi (2012), penggunaan teknologi di sekolah merupakan hal yang harus dilakukan oleh guru. Guru dapat memanfaatkan teknologi sebagai media pembelajaran. Teknologi ini dapat memudahkan guru dalam menggambarkan atau mengilustrasikan materi yang sedang dipelajari. Hal tersebut akan memperjelas antara teori dengan praktik sehingga siswa mampu melihat secara nyata. Selain itu, guru juga dapat menggunakan media pembelajaran yang berhubungan dengan teknologi untuk memperluas dan memperdalam pengetahuan untuk dirinya dan juga siswa. Peraturan Menteri Pendidikan dan Kebudayaan RI Nomor 81A Tahun 2013 menyatakan bahwa prinsip pengembangan rencana pelaksanaan pembelajaran dalam Kurikulum 2013 harus menerapkan teknologi, informasi, dan komunikasi dalam proses pembelajaran. Untuk itu, guru dituntut agar dapat memanfaatkan teknologi dengan baik.

Perkembangan teknologi yang semakin cepat tersebut saat ini dilandasi oleh perkembangan matematika di berbagai bidang. Matematika merupakan salah satu bidang studi yang mendukung perkembangan ilmu pengetahuan dan teknologi (Sundayana, 2013). Matematika perlu diberikan kepada semua siswa mulai dari SD untuk membekali siswa dengan kemampuan berpikir yang logis dan kritis. Sebagai seorang pendidik, guru harus dapat meningkatkan kemampuannya dalam menguasai teknologi sehingga mampu memberikan pelajaran matematika yang sesuai dengan kebutuhan saat ini.

Berdasarkan observasi yang dilakukan di kelas IV SDN Karangtumaritis, kemampuan siswa dalam memahami mata pelajaran matematika masih rendah. Kurangnya pemanfaatan media pembelajaran dapat menjadi salah satu faktor rendahnya pemahaman siswa terhadap mata pelajaran matematika. Selain itu, masih banyaknya siswa terlihat kurang antusias dan asyik mengobrol dengan temannya. Mereka tidak memperhatikan guru saat menjelaskan materi yang sedang dipelajari. Hal tersebut dapat berdampak terhadap ren- dahnya kemampuan siswa memahami konsep yang berkaitan dengan matematika, padahal pelajaran matematika ini sangat berguna untuk diterapkan dalam kehidupan sehari-hari dimana kita pastinya akan melakukan transaksi uang, menghitung waktu, menjumlahkan barang, dan sebagainya.

Masalah selanjutnya yang peneliti temukan dalam observasi di kelas IV SDN Karangtumaritis yaitu kurangnya pemahaman siswa terhadap materi keliling dan luas bangun datar. Sebagian besar siswa belum dapat menentukan rumus keliling dan luas bangun datar. Siswa masih melihat rumus yang ada di buku dan kesulitan dalam mengerjakan latihan soal yang diberikan oleh guru. Kurangnya pemahaman siswa disebabkan karena guru hanya mengajak siswa untuk menghafal rumus keliling dan luas bangun datar tanpa menjelaskan cara menentukan rumus tersebut. Hal tersebut akan berdampak negatif kepada hasil belajar siswa karena siswa hanya cenderung menghafal tanpa memahaminya yang tentunya akan membuat siswa cepat lupa dengan hafalannya.

Pembelajaran yang dilakukan tersebut kurang bermakna bagi siswa dan cenderung hanya berpusat pada guru. Guru harus mampu menciptakan pembelajaran matematika yang efektif dan efisien dengan menanamkan konsep pada siswa agar siswa mampu memahami dan mengingat materi dalam jangka waktu yang lama sehingga hasil belajarnya pun meningkat dan tidak terjadi miskonsepsi terhadap materi yang dipelajari.

Menurut Mulyasa (2016), pembelajaran harus sebanyak mungkin melibatkan siswa agar mereka mampu bereksplorasi untuk membentuk kompetensi dengan menggali berbagai potensi. Untuk itu, perlunya kreativitas guru agar mereka mampu menjadi fasilitator dan mitra belajar bagi siswa. Kreativitas guru dapat dilakukan dengan membuat dan mengembangkan media pembelajaran serta alat peraga lain yang berguna bagi peningkatan kualitas pembelajaran.

Media pembelajaran perlu dikembangkan dengan memanfaatkan teknologi yang didukung dengan ketersediaan fasilitas yang ada di sekolah. Media pembelajaran dalam 
bentuk video merupakan salah satu alternatif yang tepat untuk digunakan di SDN Karangtumaritis karena di SD tersebut tersedia fasilitas yang mendukung penggunaan video. Menurut Munir (2015), salah satu kelebihan dari video yakni dapat memperkaya penyajian atau penjelasan secara efektif dan efisien. Guru dapat menggunakan beberapa aplikasi yang dapat disajikan dalam bentuk video, diantaranya yaitu videoscribe, PowToon, animaker, dan sebagainya. Villar mengemukakan bahwa PowToon merupakan aplikasi berbasis web yang disediakan bagi pengguna untuk membuat video animasi dengan memanipulasi benda, gambar impor, menyediakan musik dan pengguna dapat menambahkan suara (Andrianti, 2016).

Penggunaan media pembelajaran animasi PowToon ini didasarkan pada penelitian sebelumnya yang dilakukan oleh Asyifa (2018) yang menyatakan bahwa video pembelajaran yang dibuat dengan PowToon layak digunakan dan dapat meningkatkan pemahaman konsep matematis siswa. Perbedaan dari penelitian ini dengan penelitian sebelumnya, yaitu 1) durasi video lebih lama, yakni kurang lebih 13 menit; 2) berbagai animasi digunakan untuk dijadikan suatu ilustrasi yang berkaitan dengan kehidupan sehari-hari; dan 3) menggunakan rekaman suara sebagai pendukung untuk memperjelas materi yang disajikan.

Berdasarkan permasalahan tersebut, maka peneliti melakukan penelitian berjudul "Pengembangan Media Pembelajaran Animasi Powtoon pada Mata Pelajaran Matematika di Kelas IV". Masalah yang dirumuskan berdasarkan latar belakang di atas adalah "Bagaimana proses pengembangan media pembela-

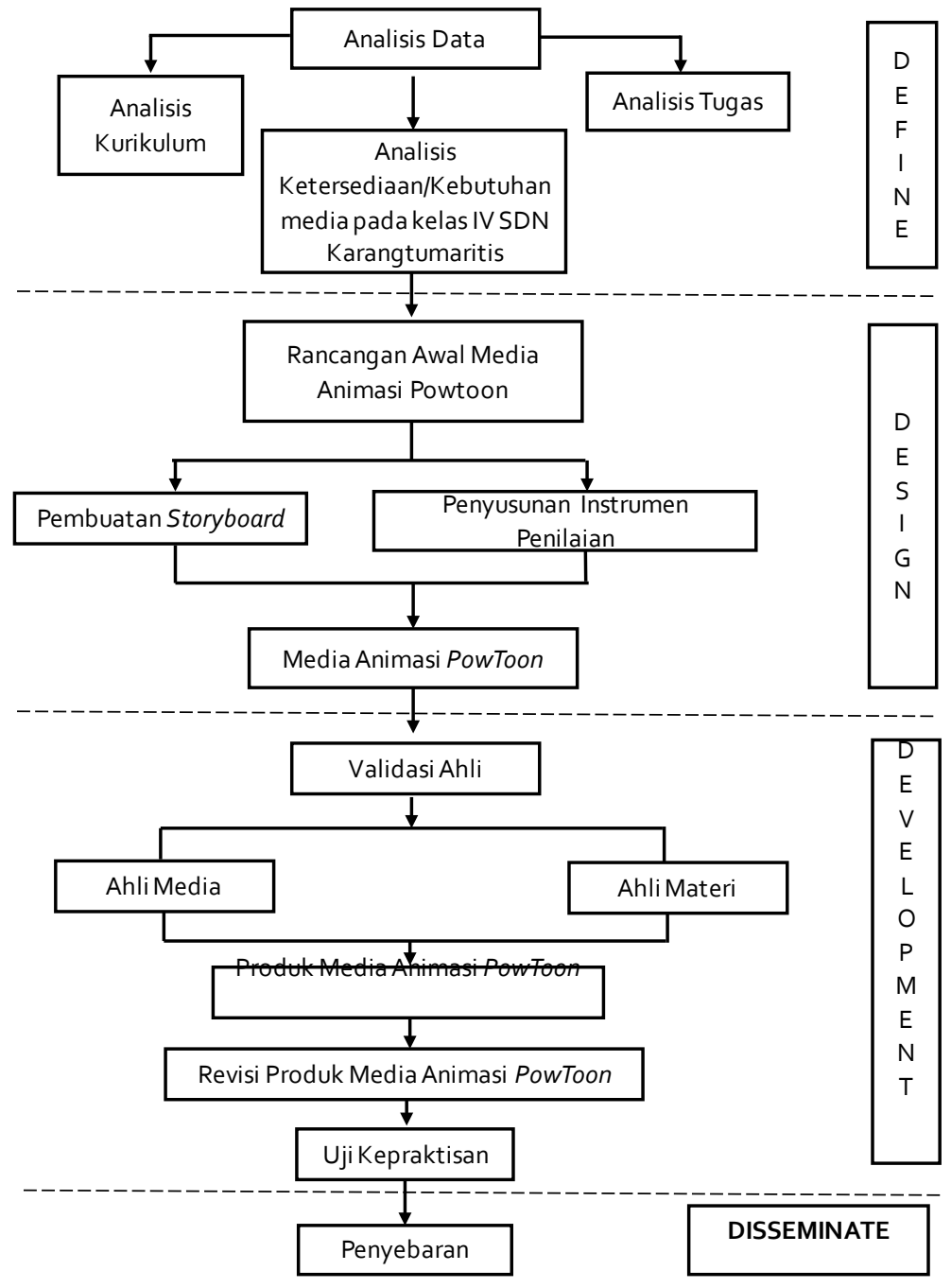

Gambar 1. Bagan Tahap Model 4-D (Trianto, 2010) 
jaran animasi PowToon pada mata pelajaran matematika materi keliling dan luas bangun datar dan implikasinya terhadap pemahaman siswa kelas IV?".

ZTabel 1. Hasil Validasi Ahli Media

\begin{tabular}{ccccc}
\hline \multirow{2}{*}{$\begin{array}{c}\text { Aspek } \\
\text { Penilaian }\end{array}$} & \multicolumn{2}{c}{ Ahli Media 1 } & \multicolumn{2}{c}{ Ahli Media 2 } \\
\cline { 2 - 5 } & Skor & $\begin{array}{c}\text { Persentase } \\
(\%)\end{array}$ & Skor & $\begin{array}{c}\text { Persentase } \\
(\%)\end{array}$ \\
\hline Tampilan & 59 & 90,77 & 65 & 100,00 \\
Penyajian & 12 & 80,00 & 14 & 93,33 \\
Efek & 16 & 80,00 & 17 & 85,00 \\
Total & 87 & 87,00 & 96 & 96,00 \\
\hline Kategori & \multicolumn{3}{c}{ Sangat Layak } & \multicolumn{3}{c}{ Sangat Layak } \\
\hline
\end{tabular}

Berdasarkan Tabel 1, maka dapat disimpulkan bahwa uji kelayakan oleh ahli media pertama dan ahli media kedua memperoleh persentase yang termasuk dalam kategori sangat layak. Persentase dari hasil validasi kedua ahli media tersebut berada pada rentang $80<N P \leq 100$ dengan kategori sangat layak sehingga media animasi PowToon layak digunakan dalam pembelajaran matematika di kelas IV.

\section{Ahli Materi}

Ahli materi berperan untuk memvalidasi media dari segi isi dan penyajian materi. Uji kelayakan media dilakukan oleh ahli media dari UIN Sultan Maulana Hasanuddin Banten. Berikut adalah analisis data validasi dari ahli materi.

Tabel 2. Hasil Validasi Ahli Materi

\begin{tabular}{ccccc}
\hline \multirow{2}{*}{$\begin{array}{c}\text { Aspek } \\
\text { Penilaian }\end{array}$} & \multicolumn{2}{c}{ Ahli Materi 1 } & \multicolumn{2}{c}{ Ahli Materi 2 } \\
\cline { 2 - 5 } & Skor & $\begin{array}{c}\text { Persentase } \\
(\%)\end{array}$ & Skor & $\begin{array}{c}\text { Persentase } \\
(\%)\end{array}$ \\
\hline Isi & 53 & 88,33 & 48 & 80,00 \\
Penyajian & 35 & 87,50 & 35 & 87,50 \\
Total & 88 & 88,00 & 83 & 83,00 \\
\hline Kategori & \multicolumn{2}{c}{ Sangat Layak } & \multicolumn{2}{c}{ Sangat Layak } \\
\hline
\end{tabular}

Berdasarkan Tabel 2, maka dapat disimpulkan bahwa uji kelayakan oleh ahli materi pertama memperoleh persentase yang termasuk dalam kategori sangat layak. Persentase dari hasil validasi kedua ahli media tersebut berada pada rentang $80<N P \leq 100$ dengan kategori sangat layak sehingga media animasi
PowToon layak digunakan dalam pembelajaran matematika di kelas IV.

\section{Revisi Produk}

Setelah dilakukan tahap validasi, kemudian media animasi PowToon diperbaiki kekurangannya berdasarkan komentar dan saran dari para ahli. Para ahli memberikan komentar bahwa video ini sudah baik dan bisa digunakan untuk uji lapangan. Ada beberapa saran yang diberikan oleh para ahli, diantaranya yaitu 1) contoh soal baiknya dimasukkan suara; 2) tambahkan aktivitas keterlibatan siswa; 3) tambahkan indikator dan tujuan pembelajaran; 4) durasi pada bagian contoh soal lebih diperpanjang; dan 5) gunakan pendekatan induktif.

Berdasarkan komentar dan saran di atas, maka media animasi PowToon perlu direvisi meskipun sudah layak digunakan. Adapun revisi yang telah dilakukan pada pengembangan media animasi PowToon ini, yaitu 1) sudah memasukkan suara pada setiap contoh soal; 2) sudah menambahkan aktivitas siswa dengan menambahkan durasi pada bagian pertanyaan "tahukah kamu?" agar siswa dapat ikut terlibat; 3) sudah menambahkan indikator dan tujuan pembelajaran dalam dua slide; 4) sudah memperpanjang durasi pada contoh soal dari 20 detik menjadi 40 detik; dan 5) sudah menggunakan pendekatan induktif pada rumus keliling persegi.

\section{Uji Kepraktisan}

Media pembelajaran animasi PowToon yang telah divalidasi serta direvisi sesuai dengan komentar dan saran dari para ahli, kemudian diujikan kepraktisannya melalui respon guru. Respon guru berperan untuk menilai media dari segi teknis, penyajian, dan kualitas dari media tersebut. Respon guru dilakukan oleh guru kelas IV di SDN Karangtumaritis. Berikut adalah analisis data penilaian kepraktisan dari respon guru.

Berdasarkan Tabel 3, maka dapat disimpulkan bahwa uji kepraktisan dari respon guru memperoleh persentase 93,33\% dengan kategori sangat praktis. Persentase dari hasil respon guru tersebut berada pada rentang $80<N P \leq 100$ dengan kategori sangat praktis sehingga media animasi PowToon praktis di- 
gunakan dalam pembelajaran matematika di kelas IV.

\begin{tabular}{|c|c|c|c|}
\hline $\begin{array}{c}\text { Aspek } \\
\text { Penilaian }\end{array}$ & Skor & $\begin{array}{c}\text { Persentase } \\
(\%)\end{array}$ & Kategori \\
\hline Teknis & 31 & 88,57 & Sangat Praktis \\
\hline Penyajian & 20 & 100,00 & Sangat Praktis \\
\hline $\begin{array}{c}\text { Kualitas } \\
\text { Media }\end{array}$ & 19 & 95,00 & Sangat Praktis \\
\hline Total & 70 & 93,33 & Sangat Praktis \\
\hline
\end{tabular}

\section{Respon Siswa}

Respon siswa berperan untuk menilai media dari segi teknis, penyajian, dan kualitas dari media tersebut. Respon siswa dilakukan oleh siswa kelas IV di SDN Karangtumaritis dengan jumlah 22 siswa. Berikut adalah analisis data penilaian respon siswa.

Tabel 4. Hasil Respon Siswa

\begin{tabular}{ccc}
\hline Aspek Penilaian & $\begin{array}{c}\text { Persentase } \\
(\%)\end{array}$ & Kategori \\
\hline Teknis & 95,71 & Sangat Baik \\
Penyajian & 93,64 & Sangat Baik \\
Kualitas Media & 94,09 & Sangat Baik \\
\hline Total & 94,73 & Sangat Baik \\
\hline
\end{tabular}

Berdasarkan Tabel 4, maka dapat disimpulkan bahwa hasil dari respon siswa memperoleh persentase $94,73 \%$ dengan kategori sangat baik. Persentase dari hasil respon siswa tersebut berada pada rentang $80<N P \leq 100$ dengan kategori sangat baik sehingga media animasi PowToon dapat membuat siswa tertarik dengan mata pelajaran matematika di kelas IV.

\section{Pemahaman Siswa}

Pemahaman siswa kelas IV setelah menggunakan media animasi PowToon diukur dengan pemberian post test yang terdiri dari empat soal uraian. Pemberian post test dilakukan pada tanggal 1 Maret 2019. Indikator keberhasilan dari pemahaman siswa ini yaitu apabila nilai rata-rata post test siswa kelas IV memenuhi minimal kategori pemahaman yaitu baik. Post test yang diberikan kepada siswa didapatkan hasil sebagai berikut.

Tabel 5. Hasil Post Test Siswa Kelas IV

\begin{tabular}{cc}
\hline Statistik & Post Test \\
\hline Jumlah Siswa & 22 \\
Nilai Terendah & 55 \\
Nilai Tertinggi & 100 \\
\hline Nilai Rata-rata & 76,14 \\
\hline
\end{tabular}

Berdasarkan Tabel 5, maka dapat diketahui bahwa skor maksimum yang diperoleh dari post test yaitu 100, sedangkan skor minimum yang diperoleh yaitu 55 . Skor rata-rata yang diperoleh adalah 76,14 yang termasuk ke dalam kategori baik. Oleh karena itu, dapat disimpulkan bahwa media animasi PowToon dapat memberikan pemahaman kepada siswa karena nilai rata-rata yang diperoleh termasuk dalam kategori baik.

\section{Tahap Penyebaran (Disseminate)}

Media pembelajaran animasi PowToon yang dihasilkan pada akhir pengembangan disebarkan secara terbatas hanya kepada guru kelas IV di SDN Karangtumaritis. Penyebarannya dilakukan dengan memberikan media animasi PowToon dalam bentuk CD dan di-upload ke Youtube sehingga dapat digunakan secara berulang-ulang.

\section{PEMBAHASAN}

Media yang dipilih dalam pengembangan ini adalah media pembelajaran animasi PowToon karena PowToon lebih banyak menyediakan animasi daripada aplikasi lainnya. Animasi tersebut juga dapat diatur dengan mudah sesuai dengan keinginan penggunanya sehingga mudah digunakan untuk memberikan suatu ilustrasi yang berkaitan dengan materi yang akan disajikan. Animasi PowToon adalah suatu aplikasi yang memiliki fitur canggih dalam satu layar, yang dapat membuat berbagai animasi sesuai kebutuhan yang diperlukan. Dalam pembelajaran tersebut juga dikemukakan bahwa animasi memiliki banyak keunggulan, seperti dapat menghilangkan kejenuhan dalam pembelajaran, membangkitkan gairah belajar, dan tentunya animasi dapat menarik perhatian siswa agar tetap fokus dalam proses belajar (Hasbulah, 2018).

Pengembangan media pembelajaran animasi PowToon dikemas dengan konten yang berisi suatu ilustrasi terkait materi keli- 
ling dan luas bangun datar (persegi, persegi panjang, dan segitiga). Konten tersebut disesuaikan dengan tujuan pembelajaran yang ingin dicapai dari proses pembelajaran dengan menggunakan media animasi ini berbentuk video. Pembelajaran menggunakan media video dilakukan agar penyampaian materi dapat lebih menarik dan jelas (Latif, 2013).

Keberhasilan dari pengembangan media pembelajaran animasi PowToon dalam mata pelajaran matematika di kelas IV dibuktikan melalui validasi media oleh ahli media dan ahli materi, respon guru dan siswa, serta pemahaman siswa setelah menggunakan media pembelajaran ini. Uji validasi yang telah dilakukan oleh ahli media pertama dari segi tampilan memperoleh presentase sebesar $90,77 \%$, dari segi penyajian memperoleh presentase sebesar $80 \%$, dan dari segi efek memperoleh presentase sebesar $80 \%$. Uji kelayakan oleh ahli media pertama memperoleh persentase $87 \%$ dengan kategori sangat layak.

Uji validasi yang telah dilakukan oleh ahli media kedua dari segi tampilan memperoleh presentase sebesar $100 \%$, dari segi penyajian memperoleh presentase sebesar $93,33 \%$, dan dari segi efek memperoleh presentase sebesar $85 \%$. Uji kelayakan oleh ahli media kedua memperoleh persentase $96 \%$ dengan kategori sangat layak.

Selain itu, uji validasi yang telah dilakukan oleh ahli materi pertama dari segi isi memperoleh presentase sebesar $88,33 \%$ dan dari segi penyajian memperoleh presentase sebesar $87,5 \%$. Uji kelayakan oleh ahli materi pertama memperoleh persentase $88 \%$ dengan kategori sangat layak. Sedangkan, uji validasi yang telah dilakukan oleh ahli materi kedua dari segi isi memperoleh presentase sebesar $80 \%$ dan dari segi penyajian memperoleh presentase sebesar $87,5 \%$. Uji kelayakan oleh ahli materi pertama memperoleh persentase $83 \%$ dengan kategori sangat layak.

Validasi media pembelajaran animasi PowToon oleh para ahli secara keseluruhan mendapatkan presentase sebesar $88 \%$ yang termasuk dalam kategori sangat layak. Uraian tersebut menunjukkan bahwa media pembelajaran ini sangat layak digunakan dalam proses pembelajaran matematika pada materi keliling dan luas bangun datar di kelas IV.

Tabel 6. Rerata Skor Validasi Ahli

\begin{tabular}{ccc}
\hline Hasil Validasi & $\begin{array}{c}\text { Persentase } \\
(\%)\end{array}$ & Kategori \\
\hline Ahli Media & 91,5 & Sangat Layak \\
Ahli Materi & 85,5 & Sangat Layak \\
\hline Rata-rata Skor & 88 & Sangat Layak \\
\hline
\end{tabular}

Media pembelajaran animasi PowToon yang telah divalidasi serta direvisi sesuai dengan komentar dan saran dari para ahli, kemudian diterapkan dalam proses pembelajaran. Peneliti melaksanakan proses pembelajaran dengan menggunakan media animasi ini sebanyak dua pertemuan, yakni pada tanggal 28 Februari 2019 dan 1 Maret 2019. Pada pertemuan pertama, peneliti mengajarkan materi mengenai keliling bangun datar (persegi, persegi panjang, dan segitiga). Pada pertemuan kedua, peneliti mengajarkan materi mengenai luas bangun datar (persegi, persegi panjang, dan segitiga).

Penggunaan media dalam pembelajaran ini bertujuan untuk mengetahui hasil dari penerapan media pembelajaran animasi PowToon dalam proses pembelajaran di kelas. Hasil yang diukur yakni pemahaman dan respon siswa pada mata pelajaran matematika, khususnya materi keliling dan luas bangun datar. Salah satu komponen yang penting di dalam pendekatan sistem untuk pendidikan dan kegiatan pembelajaran adalah pemilihan dan penggunaan media pembelajaran. Media adalah sarana yang dapat dipergunakan oleh guru untuk membagi tanggung jawab di dalam menyerahkan informasi atau isi kepada siswa (Abidin, 2011).

Hal tersebut sesuai dengan penelitian sebelumnya yang telah dilakukan oleh Widiasih (2017) bahwa penggunaan media pembelajaran yang sesuai dalam proses belajar mengajar dapat membangkitkan motivasi dan rangsangan kegiatan belajar yang berasal dari dalam diri siswa tersebut. Adanya motivasi belajar pada siswa menjadikan siswa tersebut lebih bersemangat dalam belajar sehingga hasil belajar yang diperoleh dapat optimal. Hasil belajar yang diperoleh siswa tidak hanya dilihat dari aspek kognitif saja namun juga afektif dan juga psikomotorik siswa yang 
mengalami perubahan.

Senada dengan teori di atas, Febriani (2017) mengemukakan bahwa salah satu cara untuk memicu motivasi, minat dan membangun rasa kompetensi dalam pembelajaran matematika dan sains adalah melalui penggunaan berbagai media teknologi berupa media video. Media pembelajaran yang dikemas dalam bentuk video dapat memberikan memori jangka panjang kepada siswa karena media ini disajikan melalui animasi, gambar, dan suara. Media video memiliki potensi untuk lebih disukai siswa. Hal ini dikarenakan melalui media video siswa dapat menyaksikan dan membayangkan apa yang disajikan pada saat pemutaran video berlangsung. Oleh karena itu, dengan adanya video dalam pembelajaran dapat membuat siswa dengan mudah memahami tujuan pembelajaran yang ingin dicapai.

Setelah melaksanakan proses pembelajaran dengan menggunakan media pembelajaran animasi PowToon, guru kelas IV memberikan respon terhadap media ini. Respon guru yang telah dilakukan oleh guru kelas IV SDN Karangtumaritis dari segi teknis memperoleh presentase sebesar $88,57 \%$, dari segi penyajian memperoleh presentase sebesar $100 \%$, dan dari segi kualitas media memperoleh presentase sebesar 95\%. Sedangkan, respon siswa yang telah dilakukan oleh siswa kelas IV SDN Karangtumaritis dari segi teknis memperoleh presentase sebesar $95,71 \%$, dari segi penyajian memperoleh presentase sebesar $93,64 \%$, dan dari segi kualitas media memperoleh presentase sebesar 94,09\%. Berdasarkan uraian di atas, media pembelajaran animasi PowToon sangat praktis dan sangat baik digunakan dalam proses pembelajaran matematika pada materi keliling dan luas bangun datar di kelas IV.

Penggunaan media pembelajaran animasi PowToon dapat memberikan pemahaman kepada siswa mengenai mata pelajaran matematika khususnya materi keliling dan luas bangun datar. Hal tersebut dapat dilihat dari rata-rata hasil post test sebesar 76,14 yang termasuk dalam kategori baik. Adanya peningkatan pemahaman siswa terdapat mata pelajaran matematika merupakan hasil dari proses pembelajaran dengan menggunakan media animasi PowToon ini. Sebagian besar siswa terlihat lebih antusias untuk menyimak materi yang disajikan dalam media pembelajaran ini sehingga mereka dapat memahami materi yang disajikan. Hal tersebut dikarenakan media pembelajaran ini mengandung unsur 3D yang dapat mencakup gaya belajar siswa yang berbeda-beda yakni visual, auditori, dan kinestetik sehingga proses pembelajaran matematika menjadi lebih bermakna.

Hal tersebut sesuai dengan teori yang dikemukakan oleh Heruman (2008) bahwa dalam proses pembelajaran matematika di SD diharapkan adanya reinvention (penemuan kembali) secara informal dalam pembelajaran di kelas dan harus menampakkan adanya keterkaitan antar konsep. (Susilo, 2015) juga mengemukakan bahwa konsep-konsep matematika tersusun secara hierarki, terstruktur, logis dan sistematis mulai dari konsep yang paling sederhana sampai kepada konsep yang paling kompleks. Dalam matematika terdapat topik atau konsep prasyarat sebagai dasar untuk memahami topik atau konsep selanjutnya. Hal ini bertujuan untuk memberikan pembelajaran yang bermakna bagi siswa.

Berdasarkan pembahasan hasil pengembangan media pembelajaran animasi PowToon pada mata pelajaran matematika materi keliling dan luas bangun datar di kelas IV, maka media tersebut dianggap berhasil dikembangkan menjadi media yang lebih baik karena layak digunakan dan telah dikemas secara praktis sesuai dengan tahap pengembangan serta mampu memberikan kebermanfaatan bagi siswa yakni memberikan pemahaman kepada siswa mengenai mata pelajaran matematika materi keliling dan luas bangun datar.

\section{SIMPULAN}

Berdasarkan hasil penelitian dan pembahasan, maka dapat disimpulkan bahwa media pembelajaran animasi PowToon dengan menggunakan model 4-D telah dikembangkan berdasarkan hasil kritik dan saran dari para ahli sehingga dapat diuji cobakan di kelas IV SDN Karangtumaritis. Hasil post test yang dilakukan oleh siswa kelas IV SDN Karangtumaritis memperoleh skor rata-rata sebesar 76,14 yang termasuk dalam kategori baik. 
Dengan demikian, media pembelajaran animasi PowToon dapat memberikan pemahaman kepada siswa mengenai mata pelajaran matematika di kelas IV materi keliling dan luas bangun datar.

\section{DAFTAR PUSTAKA}

Abidin, Z, dan Saputro, TME. (2011). Upaya Meningkatkan Motivasi dan Pemahaman Siswa pada Materi Geometri dan Pengukuran Melalui Kegiatan "Remase" di SMP 33 Semarang, Kreano, Jurnal Matematika Kreatif-Inovatif, 2(2), 133-141.

Andriati, Y., \& Susanti, L. R. (2016). Pengembangan Media Powtoon Berbasis Audiovisual Pada Pembelajaran Sejarah. CRIKSETRA: Jurnal Pendidikan Sejarah, 5(9), 60.

Asyifa, S.M. (2018). Pengembangan Video Pembelajaran untuk Mengembangkan Kemampuan Pemahaman Konsep Matematis Siswa Sekolah Dasar. (Doctoral Dissertation). Serang: Universitas Sultan Ageng Tirtayasa.

Barnawi dan Arifin. (2012). Etika dan Profesi Kependidikan. Yogyakarta: Ar-Ruzz Media.

Febriani, C. (2017). Pengaruh Media Video terhadap Motivasi Belajar dan Hasil Belajar Kognitif Pembelajaran IPA Kelas V Sekolah Dasar, Jurnal Prima Edukasia, 5, 13-14.

Hasbulah. (2018). Peningkatan Hasil Belajar Kognitif Biologi Menggunakan Model Problem Base Learning Berbasi Powtoon Siswa Kelas XII IPA 7 SMA N 1 Metro Semester Ganjil Tahun Pelajaran 2017/2018, BIOEDUKASI (Jurnal Pendidikan Bi- ologi), 9(2), 124-131.

Heruman. (2008). Model Pembelajaran Matematika di Sekolah Dasar. Remaja Rosdakarya. Bandung.

Latif, Y; Darmawijoyo; dan Putri RII. (2013). Pengembangan Bahan Ajar Berbantuan Camtasia pada Pokok Bahasan Lingkaran melalui Edmodo untuk siswa MTs, Kreano, Jurnal Matematika KreatifInovatif, 4(2), 105-114.

Mulyasa, E. (2016). Pengembangan dan Implementasi Kurikulum 2013. Bandung: PT Remaja Rosdakarya.

Munir. (2015). Multimedia Konsep dan Aplikasi dalam Pendidikan. Bandung: CV Alfabeta.

Sundayana, Rostina. (2013). Media Pembelajaran Matematika. Bandung: Alfabeta.

Susilo, B.E; Sutarto, H; dan Mubarok, D. (2015). Pengembangan Perangkat Pembelajaran Geometri Ruang dengan Model Proving Theorem, Kreano, Jurnal Matematika Kreatif-Inovatif, 6(2), 170-176.

Tim Penyusun. (2013). Peraturan Menteri Pendidikan dan Kebudayaan Republik Indonesia Nomor 81A Tahun 2013 tentang Implementasi Kurikulum. Jakarta: Kemendikbud.

Trianto. (2010). Model Pembelajaran Terpadu Konsep, Strategi, dan Implementasinya dalam KTSP. Jakarta: PT Bumi Aksara.

Widiasih, JW, dan Kartini, T. (2017). Pengaruh Penggunaan Media Bervariasi dan Motivasi Belajar Terhadap Hasil Belajar Mata Pelajaran Ekonomi Siswa Kelas XI IPS SMA Negeri 2 Jember Tahun Pelajaran 2016/2017, Jurnal Pendidikan Ekonomi: Jurnal Ilmiah Ilmu Pendidikan, Ilmu Ekonomi dan Ilmu Sosial 11, no. 2 (2018): 103-107. 